\title{
PSYCHE
}

VOL. XLVI

DECEMBER, 1939

No. 4

\section{A KEY TO THE MOSQUITOES OF MASSACHUSETTS}

\author{
By George S. Tulloch, Chief Entomologist ${ }^{1}$ \\ Massachusetts Department of Public Health \\ Boston, Massachusetts
}

During the summer of 1939 the Department of Public Health of the State of Massachusetts conducted a state-wide mosquito survey with the cooperation of the Works Projects Administration. This survey was one phase in the program of a study of the general problem of encephalitis. It was initiated following an outbreak of encephalitis in man in 1938 which was traced to the eastern virus of equine encephalomyelitis. The identification of biting mosquitoes was made by using a key compiled by Tulloch (1930) which was taken from Dyar (1922) and Matheson (1929) and modified to include those species reported from New England. The present key is a revision of the earlier one which has been enlarged to include the non-biting as well as the biting mosquitoes and is based on the examination of over 100,000 specimens. Although this key is restricted to the species which may be found in Massachusetts it is sufficiently inclusive for use in any of the New England states. It is accompanied by illustrations of many of the characters of taxonomic importance and by a summary of the species of Culicidæ which have been taken in Massachusetts.

1 Grateful acknowledgment is made to the following for assistance: Dr. R. F. Feemster, Director, Division of Communicable Diseases, Massachusetts Department of Public Health; Dr. V. A. Getting, Technical Director, Massachusetts Mosquito Survey; Prof. J. C. Bequaert, Consulting Entomologist; V. A. Bell, R. P. Holdsworth, Jr., C. E. Elliott, Dr. B. W. Parker, Dr. J. W. Hawkins, G. C. Tower, H. D. Rose, and R. O. Bohm, Entomologists and to Mr. J. Milano for preparation of the plates. 
The material for this key has been modified from the works of many authors, notably Smith (1903), Headlee (1921), Dyar (1922, 1928), Dyar and Shannon (1924), Matheson (1925, 1929), Bradley (1936), Edwards (1932), Johannsen $(1903,1923,1934)$, Marshall (1938) and King, Bradley and McNeel (1939).

Mosquitoes are small two-winged insects belonging to the order Diptera, family Culicidæ. The Culicidæ are separated from all other Diptera by a characteristic wing venation which is outlined by Edwards (1932) as follows: Subcosta (Sc) long and reaching costa; radius 4 -branched, $\mathrm{R}_{2+3}$ forked, $R_{4+5}$ simple, no cross vein connecting $R_{1}$ and $R_{2}$; media two branched; cross veins r-m and m-cu both present; cubitus forked; anal vein long and reaching wing margin; axillary vein absent or very faint (Fig. 5). There is no other single character which separates the family from other Diptera. Other common family characters are (1) the small or rudimentary first antennal segment and the more or less enlarged second segment, (2) the completely divided pronotum, the posterior divisions of which appear to form part of the pleuræ. These characters, however, are not distinctive since they are shared by one or more families of Diptera.

The larvæ of the Culicidæ are distinguished from all other dipterous larvæ by the presence of a complete head capsule and of only one pair of functional spiracles situated dorsally on the eighth abdominal segment opening free to the surface (Fig. 19) or into an air tube or by the presence of a complete head capsule and air sacs in the thorax and seventh abdominal segment (Fig. 17) (Chaoborus).

Key to Subfamilies of Culicidae

Adults

1. Antennal flagellum 14 segmented; vein Sc ending above or before base of Rs (Fig. 5). Mouthparts short, wings without scales:

Dixinæ

Antennal flagellum 13 segmented; vein Sc ending much beyond base of Rs. Wings with scales at least on fringe

2. Mouthparts short, palpi incurved; scales almost confined to wing fringe: Chaoborinæ

Mouthparts modified to form a long proboscis, palpi not incurved; wing veins and legs scaly: Culicinæ 
Larvæ

1. Thorax narrow with distinct segmentation; prolegs on the first 2 abdominal segments ; tracheæ ending in a pair of discs on eighth abdominal segment (Fig. 21) : Dixinx

Thorax distinctly broader than abdomen, without distinct segmentation, paired prolegs lacking 2

2. Antennæ prehensile, with long and strong apical spines (Fig. 17) : Chaoborinæ Antennæ not prehensile (Fig. 8) : Culicinæ

\section{Subfamily Dixinæ}

This group is represented by the single genus Dixa.

Key to the Genus Dixa

\section{Adults}

1. Tips of hind tibiæ noticeably enlarged, deep black, sharply contrasting with the remainder of the member; wing veins with clouded margins; proboscis black, halteres yellowish, scutellum fuscous testaceous ; terminal clasper segment tapering, mesal process of the basal segment simple, elongate:__clavata Tips of hind tibiæ not so sharply differentiated 2

2. Petiole of $R_{2+3}$ (measured on a straight line from its base to base of fork) less than $3 / 8$ as long as $R_{3}$; proboscis, scutellum, and knob of the halteres yellow; crossvein of wing very feebly clouded, $r-m$ crossvein slightly distad of the base of $\mathrm{R}_{4+5}$ :_terna

Wing with other characters 3

3. Wing with one distinct spot 4

Wing spot very indistinct or wanting _ 5

4. Petiole of $R_{2+3}$ and $R_{3}$ subequal in length; proboscis and scutellum blackish: centralis

Petiole shorter; proboscis and scutellum yellowish:

notata

5. Dorsum of the thorax as well as the upper part of the pleura black; proboscis, halteres and scutellum dark: fusca

Dorsum of the thorax yellowish with thoracic darker 
stripes which may be more or less confluent; palpi dark

6. First tarsal joint of fore leg about $2 / 3$ as long as the tibia: cornuta

First tarsal joint of fore leg about $3 / 4$ as long as the tibia

7. Apical segment of the clasper of the male fully as broad beyond the middle as at the base; Sc ends about opposite the base of $\mathrm{Rs}$; distance between the crossveins measured on the media usually not exceeding $1 / 2$ the length of the m-cu crossvein: modesta

Apical segment of the clasper of the male tapering; Sc ends distinctly proximad of the base of Rs; distance between the crossveins about equal to the length of the m-cu crossvein : similis

\section{Larvæ}

Only two of the species given in the key above are known in the larval stage, D. modesta Joh. and D. cornuta (Joh.) which may be separated by using the key by Johannsen (1934).

\section{Subfamily Chaoborinæ}

Key to Genera

Adults

1. Clypeus small and nearly bare; $R_{1}$ ending far from tip of $\mathrm{R}_{2}$ : Corethrella Clypeus larger and very hairy; $R_{1}$ ending close to tip of $\mathrm{R}_{2}$ 2

2. First tarsal segment much shorter than second:

First tarsal segment longer than second Mochlonyx

3. Clypeus as long as head; claws larger and toothed: Eucorethra

Clypeus shorter than head; claws small and simple: Chaoborus

\section{Larvæ}

1. Eighth abdominal segment with an elongate single dorsal respiratory siphon or air tube 
Eighth abdominal segment without an elongate single dorsal air tube; with a flattened spiracular disc on the eighth segment or with air sacs in the thorax and the seventh abdominal segment 3

2. Antennæ inserted close together, folding outwardly and fitting into grooves on the head (Fig. 20) :

Corethrella

Antennæ inserted far apart, pendent in resting position (Fig 18) : Mochlonyx

3. Air sacs present in thorax and seventh abdominal segment (Fig. 17) : Chaoborus

Air sacs absent, a well-developed spiracular disc on eighth abdominal segment (Fig. 19) : ___Eucorethra

Key to the Genus Chaoborus

Adults

1. Wings spotted or clouded 2

Wings without spots or clouds 4

2. Width of hind marginal wing fringe nearly as great as distance between cubitus and hind margin 3

Hind marginal wing fringe less than half the distance between cubitus and hind margin: trivittatus

3. Femora and tibiæ with numerous distinct spots: punctipennis

Femora and tibiæ without distinct spots except at bases and apices: albatus

4. Mesonotum with dark longitudinal bands : _- americanus Mesonotum with yellowish red longitudinal bands: albipes

\section{Larvæ*}

1. Pre-labral leaf-like appendages very narrow and lanceolate: punctipennis Pre-labral leaf-like appendages less than seven times as long as broad

2. Mandibular fan with 25 or more rays:_americanus Mandibular fan with not over 18 rays ________

3. Mandibular fan with $16-18$ rays:_trivittatus Mandibular fan with not more than 12 rays:_-_albipes

* Larva of $C$. albatus is unknown. 
Key to the Genus Mochlonyx

Adults

1. Wing vestiture entirely pale yellow

Wing vestiture black and yellow: cinctipes

2. Scutellar setæ numerous, arranged in two or three irregular rows : karnerensis Scutellar setæ sparse, arranged in a single row:

fuliginosus

\section{Larvæ*}

1. Clypeal and frontal spines barbed from base to a little beyond middle: karnerensis These spines with long barbs beyond middle: _._._inctipes

* The larva of $M$. fuliginosus is unknown.

The following genera of the Chaoborinæ are represented by single species: Corethrella brakeleyi Coquillett and Eucorethra underwoodi Underwood.

\section{Subfamily Culicinæ}

KEY TO GENerd

Adults

1. Postnotum with a median tuft of setæ located near the posterior margin (Fig. 2) : Wyeomyia

Postnotum without a tuft of setæ 2

2. Wings with the second marginal cell not half as long as its petiole (Fig. 5) : Uranotænia

Wings with the second marginal cell more than half as long as its petiole

3. Scutellum rounded or crescent-shaped with an even fringe of marginal setæ (Fig. 3) : Anopheles

Scutellum distinctly trilobed (Fig. 4) with marginal setæ aggregated on the lobes

4. Spiracular bristles present (Fig. 2)

Spiracular bristles absent 6

5. Post-spiracular bristles present (Fig. 2) ; abdomen of female with the eighth segment wholly retractile:

Psorophora

Post-spiracular bristles absent; cross veins of wings 
tending to lie in line, or mesonotum with bare areas devoid of scales or both: Theobaldia

6. Pronotal bristles only two stout setæ (Fig. 2) ; proboscis with black and white scales so arranged as to form longitudinal striæ; mesonotum with six longitudinal lines of white scales : Orthopodomyia

Pronotal bristles more than two, generally a prominent row; proboscis without longitudinal striæ; mesonotum without six longitudinal lines of white scales

7. Wings with scales distinctly large and broad ; first joint of all tarsi with broad median rings; all of the other tarsal joints black with basal half white scaled:

Mansonia

Wings with scales normal; tarsi not as above 8

8. Post-spiracular bristles present; female usually with the abdomen pointed and the cerci exserted or tarsi with white rings on both ends of joints : Aedes

Post-spiracular bristles absent; female with a blunt abdomen; tarsi without white rings involving both ends of joints :

Culex

\section{Larvæ}

1. Eighth segment of abdomen provided with a distinct, elongate respiratory or air tube (Fig. 8) ___ 2

Eighth segment of abdomen without a distinct, elongate respiratory or air tube (Fig. 9) : Anopheles

2. Air tube without a pecten (Fig. 12)

Air tube with a pecten (Fig. 8) ____________

3. Air tube about twice as long as wide, the apical portion sharply attenuated and provided with saw-like teeth dorsally for penetrating into plant tissues (Fig. 12) ; larva found attached to the roots of certain aquatic plants : Mansonia

Air tube about three times as long as wide, tapering more or less uniformly to the apex

4

4. Air tube with many short single hairs; larva found in the water of the pitcher plant: Wyeomyia Air tube without scattered single hairs but with a large pair of hair tufts before the middle; abdomen 
with dorsal chitinous plates on the sixth, seventh and eighth segments : Orthopodomyia

5. Head elongate, elliptical; head hairs single, stout like heavy spines: Uranotænia Head nearly circular or transverse; head hairs not like heavy spines 6

6. Air tube with several pairs of ventral tufts: Culex Air tube with a single pair of ventral tufts or with a single pair of tufts and a median ventral row of 10 to 12 unpaired tufts or without any paired ventral tufts

7. Air tube with the paired hair tufts placed close to the base between the pecten rows : Theobaldia Air tube with the paired hair tufts placed near or beyond the middle 8

8. Anal segment ringed by the dorsal plate, with tufts of the ventral brush piercing the ring: Psorophora Anal segment not ringed by the dorsal plate, or if ringed, the tufts of the ventral brush posterior to the ring: Aedes

Key to the Genus Aedes

\section{Adults}

1. Proboscis of female ringed with white (Fig. 1) 2 Proboscis of female not ringed with white

2. Abdomen with a pale longitudinal dorsal stripe (Fig. 1) ; wings with black and white scales : sollicitans

Abdomen without a pale longitudinal dorsal stripe; wings with black scales: tæniorhynchius

3. Tarsi with white rings on at least some of the segments (Fig. 1) 4 Tarsi without white rings 11

4. White tarsal rings involving both ends of segments - 5 White tarsal rings basal only 7

5. Wings scales markedly bicolored: dorsalis Wings scales uniformly dark, or nearly so 6

6. Mesonotum uniformly reddish brown, or nearly so: canadensis Mesonotum pale with a broad dark medium stripe; abdomen rather bluntly rounded: atropalpus 
7. Tarsi with pale broad rings especially on hind legs; wings scales bicolored

Tarsi with narrow rings; wing scales uniformly dark or nearly so

8. Lower mesepimeral bristles absent:

Lower mesepimeral bristles present (Fig. 2) excrucians

9. With three to five lower mesepimeral bristles; mesonotum bronzy-brown on the disc, the scales on the antescutellar space, lateral margins and a sub-dorsal line each side of the disc whitish: stimulans

With two lower mesepimeral bristles; mesonotum with a broad median stripe of yellowish brown scales, the anterior edge, the sides of the disc and antescutellar space with yellowish white to white scales :-_fitchii

10. Last two abdominal segments nearly entirely white scaled, venter entirely yellowish white: cantator

Last two abdominal segments with apical and basal bands; venter with each segment with a median black spot or stripe which may be joined to lateral black spots forming a $\mathrm{Y}$ : vexans

11. Lower mesepimeral bristles absent Lower mesepimeral bristles present 12

12. Mesonotum with silvery scales 17

Mesonotum without silvery scales 15

13. Mesonotum silvery on the sides with a dark brown median stripe which widens behind the middle and which is divided by the antescutellar space, the antescutellar space is margined by silvery scales:

triseriatus

Mesonotum with a medium silvery stripe reaching scutellum or entirely silvered

14

14. Mesonotum with a broad well-defined median silvery stripe: atlanticus

Mesonotum with a narrower poorly defined or diffuse median stripe; mesonotum of male entirely silvery; a very small blackish species : dupreei

15. Abdomen with a continuous lateral white line; mesonotum uniformly colored with golden-brown scales, paler about the antescutellar space: cinereus Abdomen without a continuous lateral white line; me- 
sonotum with a median dark band 16

16. Mesonotum with two yellow or yellowish-white stripes separated by a narrow, dark brown median band; sides dark brown to black: trivittatus

Mesonotum with the golden brown median stripe slightly constricted at the middle; with two short sublateral stripes posteriorly: hirsuteron

Mesonotum with the median band widening posteriorly; apical margins of abdominal segments with fine long brownish hairs : aurifer

17. With one to three small mesepimeral bristles; mesonotum with brownish-yellow scales uniformly distributed: intrudens

With three or more stout mesepimeral bristles ; mesonotum with a median stripe or paired brown median lines 18

18. Mesonotum with paired brown median lines 19

Mesonotum with a median brown stripe 20

19. Mesonotum yellow or bronzy with a pair of black median lines, often joined into a median stripe; legs deep black: diantæus

Mesonotum with paired median lines separated by a broad golden brown line: impiger Mesonotum with paired median lines separated by a narrow yellow line; sides grayish: communis

20. Mesonotum with the median band laterally expanded near the middle: trichurus Mesonotum with the median band only slightly darker than the lateral margins: punctor* implacabilis*

*There are no satisfactory characters with which to separate these species. In $A$. punctor the median band of the mesonotum may in some cases have a middle line of slightly paler scales. The last abdominal segment of A. implacabilis is usually pale scaled whereas in punctor it has a V-shaped dark area.

\section{Larvæ}

1. Air tube with tuft within pecten 2 Air tube with tuft beyond pecten 
2. Air tube with several dorsal hair tufts, anal gills normal: trichurus

Air tube without several dorsal hair tufts, anal gills large and inflated: atropalpus

3. Pecten with detached teeth outwardly (Fig. 15) _.____ 4 Pecten without detached teeth outwardly (Fig. 16) _...9

4. Antennæ enlarged basally: aurifer Antennæ not enlarged basally 5

5. Antennæ as long as head: diantæus Antennæ not as long as head 6

6. Both pairs of head hairs (Fig. 8) double:__-_excrucians Both pairs of head hairs not double

7. Lateral abdominal hairs (Fig. 8) single beyond second segment

Lateral abdominal hairs not single beyond second segment: vexans

8. Air tube $21 / 2$ to 3 times as long as wide, tuft on air tube large: intrudens

Air tube $31 / 2$ to 4 times as long as wide, tuft on air tube small, located on outer third of tube: cinereus

9. Comb scales in a single or in an irregular single row -10 Comb scales in a triangle

10. Anal segment ringed by plate 11 Anal segment not ringed by plate: triseriatus

11. Air tube five times as long as wide: dupreei Air tube 2 to $31 / 2$ times as long as wide 12

12. Dorsal brush of anal segment consisting of two pairs of long hairs: implacabilis

Dorsal brush of anal segment consisting of a pair of long hairs and a pair of dorsal tufts : atlanticus

13. Anal segment ringed by plate 14 Anal segment not ringed by plate 17

14. Upper and lower head hairs double: punctor Upper and lower head hairs single

15. Anal gills at least as long as anal segment:-_trivittatus Anal gills shorter than anal segment 16

16. Lateral abdominal hairs double on segments two to five; scale of comb with a stout apical spine: sollicitans 
Lateral abdominal hairs triple on segments three to five; scale of comb with a fringe of spines of approximately equal length: tæniorhynchus

17. Air tube at least four times as long as wide :____ fitchii Air tube three times or less as long as wide $\quad 18$

18. Head hairs single___ 19 Head hairs double or multiple _ $\quad 21$

19. Anal gills at least as long as anal segment_- 20 Anal gills much shorter than anal segment:___ dorsalis

20. Scale of comb with broad apex bearing four to seven stout spines: communis Scale of comb with single stout spine: impiger

21. Both pairs of dorsal head hairs multiple__ 22 Both pairs of dorsal head hairs not multiple____ 23

22. Anal gills budlike; found in salt water: Anal gills well developed: cantator canadensis

23. Lower head hairs double, upper triple:___hirsuteron Lower head hairs single, upper double: stimulans

Key to The Genus Timobatida

Adults

1. Tarsi with poorly defined yellowish white rings at both ends of some of the joints: morsitans Tarsi without rings on any of the joints 2

2. Scales of the wings mixed, black or brown and white especially along the costal margin; proboscis with intermixed black and white scales:

Scales of the wings all brown or black inornata

3. Mesonotum brown marked with yellowish lines or spots ; wings with some of the scales slightly aggregated along the third vein; a large species: _._. impatiens Mesonotum entirely reddish brown; wing scales normal; each abdominal segment with an apical row of coarse yellow hairs; a small species ( $4 \mathrm{~mm}$.) : melanura

Larvæ

1. Pecten produced into long hairs on outer half (Fig. 13) Pecten not produced into long hairs on outer half 
2. Both pairs of head hairs consisting of tufts having approximately six hairs, all of about equal length:

impatiens

Lower head hairs of three or four long hairs, upper head hairs multiple and shorter than the lower hairs:

inornata

3. Comb scales in a single row; air tube with a row of 10 12 median unpaired tufts along the ventral side beyond the pecten: melanura

Comb scales in a triangle; air tube without unpaired median ventral tufts beyond the pecten : _._-_morsitans

KLy TO THE Genus PSOROphora

Adults

1. Mesonotum brown with a median longitudinal stripe of brilliant golden curved scales bordered by narrow bare stripes ciliata

Mesonotum uniformly colored 2

2. Claws of the female toothed (Fig. 6) ; wing scales dark: posticata

Claws of the female not toothed (Fig. 7) ; wings uniformly marked with black and white scales: columbiæ

\section{Larvæ}

1. Both pairs of head hairs single, upper pair very short:

Both pairs of head hairs not single ciliata

2. Upper and lower pairs of head hairs multiple; pecten of three to five teeth widely separated on the basal half of the tube (Fig. 14): columbiæ Upper and lower pairs of head hairs double; pecten of three to four teeth on the basal fifth of tube; tuft of air tube absent: posticata

\section{Key to the Genus Anopheles}

\section{Adults}

1. Palpus with white markings 2 Palpus without white markings 3

2. Apical segment of palpus entirely white scaled; anal vein with three dark spots separated by white (two spots in the male) : crucians 
Apical segment of the palpus white-tipped; anal vein entirely dark without spots: walkeri

3. Costal margin of wing with two white or yellowish-white spots, a large one beyond the middle and a small one at the apical end: punctipennis

Costal margin of wing without white or yellowish-white spots

4. Fringe at apex of wing with a distinct light yellow to coppery spot: maculipennis

Fringe at apex of wing without a distinct light yellow to coppery spot

5. Wing with dark scales uniformly distributed: '- barberi Wing with the dark scales definitely aggregated to form dark spots at the base of the radical sector, at crossveins $r-m$ and $m-c u$, at fork of $R_{2}$ and $R_{3}$ and at fork of $\mathrm{M}_{1+2}$ and $\mathrm{M}_{3+4}$ : quadrimaculatus

\section{Larvæ}

1. Abdomen with plumose lateral hairs (Fig. 9) on first six segments; head hairs simple: barberi

Abdomen with plumose lateral hairs on first three segments; head hairs plumose

2. Abdominal segments 4 and 5 with two conspicuous tufted hairs (Fig. 11) (hair 0 and the antepalmate or hair 2) anterior to the palmate tuft, these hairs usually approximately equal in size and with four to nine branches; fresh water form: crucians

Abdominal segments 4 and 5 with but one conspicuous hair (antepalmate or hair 2) anterior to the palmate tuft, this hair may be single or with two or three branches

3. Abdomen with the palmate tufts on segments 3 to 7 inclusive, of similar form but those on segments 3 and 7 distinctly smaller than the others; posterior clypeal hairs (Fig. 10) long and usually single; tubercles of inner anterior clypeal hairs (Fig. 10) wide or close; brackish water form: crucians

Abdomen with the palmate tufts on segment 3 approximately equal in size to those on the succeeding segments 
4. Tubercles of inner anterior clypeal hairs separated by at least the width of one of these tubercles; antepalmate hairs on segments 4 and 5 usually single; palmate tufts on segment 2 usually well developed:

quadrimaculatus

Tubercles of inner anterior clypeal hairs so close together that another tubercle of similar size could not be placed between them

5. Inner anterior clypeal hairs not minutely feathered toward tip; antepalmate hairs of abdominal segments 4 and 5 usually double or multiple

Inner anterior clypeal hairs minutely feathered toward tip ; antepalmate hairs of abdominal segments 4 and 5 usually single: walkeri

6. Antepalmate hairs of abdominal segments 4 and 5 usually with 2 branches, rarely 1 or 3 ; posterior clypeal hairs usually with 2 branches from near base; inner anterior clypeal hairs single, unbranched:

punctipennis

Antepalmate hairs of abdominal segments 4 and 5 usually with 3 branches, rarely with 2 or 4 ; posterior clypeal hairs usually long with apical branching; inner anterior clypeal hairs unbranched or with 2 or 3 branches beyond middle: maculipennis

Key to the Genus Culex

\section{Adults}

1. Abdominal segments with transverse apical white bands : apicalis

Abdominal segments with basal white bands or none:-2

2. Abdominal segments with basal white bands 3 Abdominal segments without basal white bands : salinarius

3. Basal white band of the second abdominal segment triangularly produced medianly: pipiens Basal white band of the second abdominal segment transverse: territans

\section{Larvæ}

1. Antenna with the tuft at or before the middle territans Antenna with the tuft beyond the middle 
2. Both upper and lower head hairs multiple 3

Both upper and lower head hairs not multiple, usually single but with all variations between the complete single and complete double condition, rarely with one or two head hairs triple: apicalis

3. Air tube long and slender, about seven times as long as broad, slightly expanded before the apex; subdorsal hairs on segments three to six multiple: salinarius Air tube not over five times as long as wide tapering uniformly toward the apex; subdorsal hairs double on segments three to six: pipiens

The following genera of Culicinæ are represented by single species; Mansonia perturbans (Walker), Orthopodomyia signifera (Coquillett), Uranotænia sapphirina (Osten Sacken), Wyeomyia smithii (Coquillett).

\section{Sum Mary of SPECIES of CUlicidae Reported FRom MASSACHUSETTS}

The following species of mosquitoes were reported by Johnson (1925) :

Subfamily Dixinæ

Dixa centralis Loew

D. clavata Loew

D. cornuta Johannsen

D. modesta Johannsen

D. notata Loew

Subfamily Chaoborinæ

Mochlonynx cinctipes Coquillett as Corethra cinctipes Coquillett

M. karnerensis Felt as Corethra culiciformis (DeGeer)

M. fuliginosus Felt as Corethra fuliginosus Felt.

Chaoborus albipes (Johannsen)

C. americanus Johannsen as C. crystallina DeGeer

C. albatus Johnson

C. punctipennis Say

C. trivittatus Loew

Subfamily Culicinæ

Wyeomyia smithii (Coquillett) 
Culex apicalis Adams as C. testaceus Van der Wulp

C. territans Walker

C. salinarius Coquillett

Theobaldia melanura (Coquillett) as Culex melanurus (Coquillett)

T. morsitans (Theobald) as Culiseta dyari (Coquillett)

T. inornata (Williston) as Culiseta inornatus (Williston)

Mansonia perturbans (Walker) as Taeniorhynchus perturbans (Walker)

Psorophora ciliata (Fabricius)

$P$. posticata (Wiedemann) as $P$. sayi Dyar and Knab

Aedes trivittatus (Coquillett)

A. aurifer (Coquillett)

A. punctor (Kirby)

A. intrudens Dyar

A. hirsuteron (Theobald)

A. communis (DeGeer) as A. lazarensis (Felt and Young)

A. dorsalis (Meigen)

A. canadensis (Theobald)

A. stimulans (Walker)

A. cantator (Coquillett)

A. fitchii (Felt and Young)

A. trichurus (Dyar) as A. cineroborealis Felt and Young

A. atropalpus (Coquillett)

A. excrucians (Walker)

A. taeniorhynchus (Wiedemann)

A. sollicitans (Walker)

A. triseriatus (Say)

A. vexans (Meigen)

A. cinereus (Meigen)

A. impiger (Walker)

Uranotænia sapphirina (Osten Sacken)

Anopheles punctipennis (Say)

A. quadrimaculatus (Say)

A. maculipennis (Meigen)

A. walkeri (Theobald) 
In 1930 one additional Culicine was reported by Tulloch:

Aedes implacabilis (Walker) or Aedes abserratus (Felt and Young)

Several species new to Massachusetts have been recovered during the present survey. They are as follows:

Subfamily Chaoborinæ

Eucorethra underwoodi Underwood-Yarmouth, July 27, 1939, Armstrong

Corethrella brakeleyi Coquillett-Taunton, July 20, 1939, Collector M. W. Chambers

\section{Subfamily Culicinæ}

Psorophora columbix Dyar and Knab-Northampton, July 18, 1939, Collector W. J. Neunier

Orthopodomyia signifera (Coquillett) —Sudbury, August 28, 1939, Collector W. J. Normandin

Anopheles crucians Wiedemann-Orleans, August 29, 1939, Collector J. L. Drew

\section{Literature Cited}

Bradley, G. H., 1936. On the identification of mosquito larvæ of the genus Anopheles occurring in the United States (Diptera, Culicidæ). South. Med. Jour. 29: 859-861 illus.

Dyar, Harrison G., 1922. The mosquitoes of the United States. U. S. Natl. Mus. Proc. 62, art. 1, 119 pp.

1928. The mosquitoes of the Americas. Carnegie Inst. Wash. Pub. 337, 616 pp. illus.

Dyar, Harrison G. and Shannon, Raymond C., 1924. The American Chaoborinæ. Ins. Ins. Mens. 12: 201-216.

Edwards, F. W., 1932. Diptera, Fam. Culicidæ. 258 pp. illus. Bruxelles. In Wytsman, P., Genera Insectorum, fasc. 194.

Headlee, Thomas J., 1921. The mosquitoes of New Jersey and their control. N. J. Agr. Exp. Sta. Bull. 348. 229 pp. illus.

Johannsen, O.. A., 1903. Aquatic insects in New York State. N. Y. State Mus. Bull. 68 , part 6: 328-441. illus. 1923. North American Dixidæ. Psyche 30: 52-58. illus. nomidæ and Ceratopogonidæ. Cornell. Univ. Agr. Exp. Sta. Memoir 164. $71 \mathrm{pp}$. illus.

Johnson, Charles W., 1925. Fauna of New England 15, List of the Diptera or two-winged insects. Boston Soc. of Nat. Hist. 7. 326 pp. illus.

King, W. V., Bradley, G. H., and McNeel, T. E., 1939. The mosquitoes of the southeastern States. U. S. Dept. Agr. Misc. Pub. 336. 90 pp. illus.

Marshall, J. E., 1938. The British Mosquitoes. 341 pp. illus. William Clowes and Sons, Ltd. London and Beccles. 
Matheson, Robert, 1925. Notes on Chaoborinæ (Diptera, Culicidæ). Can. Ent. 57: 159-160.

1929. A handbook of the mosquitoes of North America. $268 \mathrm{pp}$. illus. Springfield, Ill. and Baltimore, Md.

Smith, John B., 1904. Report of the New Jersey State Agricultural Experiment Station upon the mosquitoes occurring within the state, their habits, life history, etc. $482 \mathrm{pp}$. illus. Trenton.

Tulloch, George S., 1930. A key to the biting mosquitoes of New England. Psyche 37: 234-244. illus.

\section{Explanation of Plates}

Plate 4

1. Female mosquito (after John B. Smith).

\section{Plate 5}

2. Side view of thorax showing bristle areas.

3. Dorsal view of crescent-shaped scutellum.

4. Dorsal view of trilobed scutellum.

5. Generalized wing of a mosquito.

6. Tarsus with toothed claws.

7. Tarsus with simple claws.

\section{Plate 6}

8. Larva of Aedes (after Marshall).

9. Larva of Anopheles (after Marshall).

\section{Plate 7}

10. Head of Anopheles larva (after Marshall).

11. Dorsal view of segments 4 and 5 of Anopheles larva.

12. Air tube sharply attenuated without a pecten.

13. Air tube with some of the pecten teeth produced into long hairs.

14. Air tube fusiform with small tuft (after Dyar).

15. Air tube with pecten teeth detached outwardly.

16. Air tube with pecten teeth not detached outwardly.

\section{Plate 8}

17. Larva of Chaoborus (after Johannsen).

18. Larva of Mochlonyx (after Johannsen).

19. Larva of Eucorethra (after Johannsen).

20. Larva of Corethrella (after Johannsen).

21. Larva of Dixa (after Johannsen). 


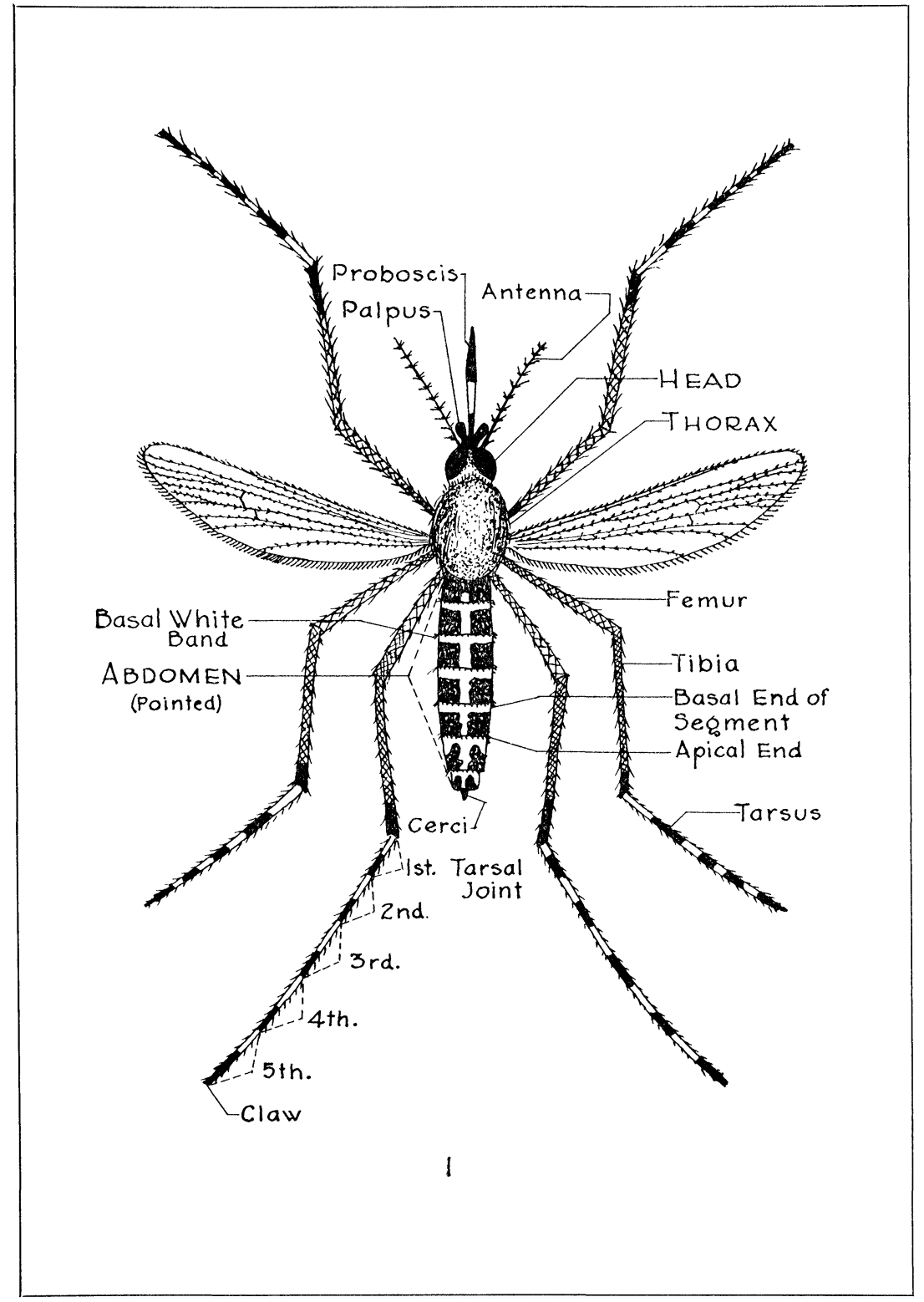

Tulloch - Mosquitoes of Massachusetts. 


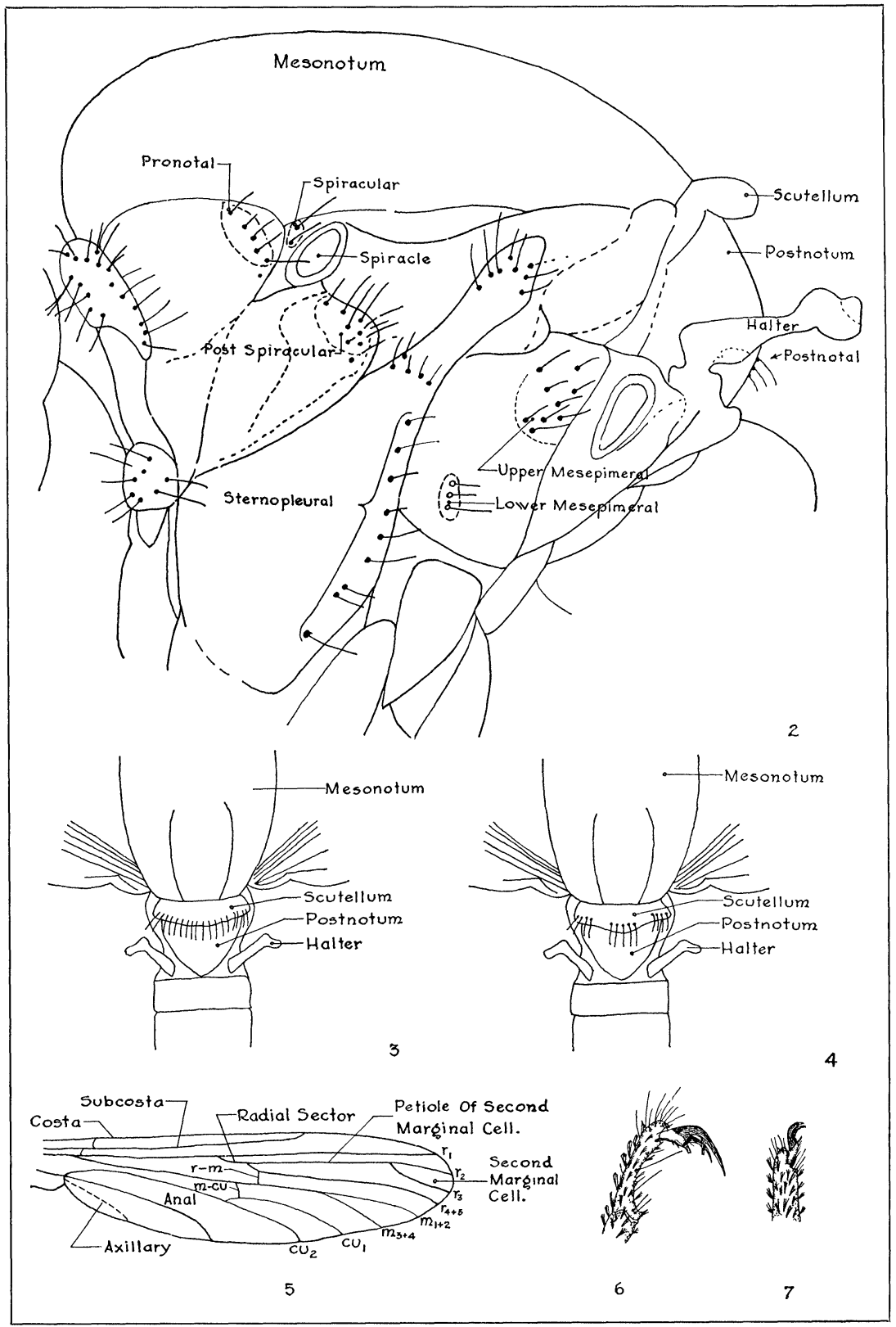

Tulloch - Mosquitoes of Massachusetts. 

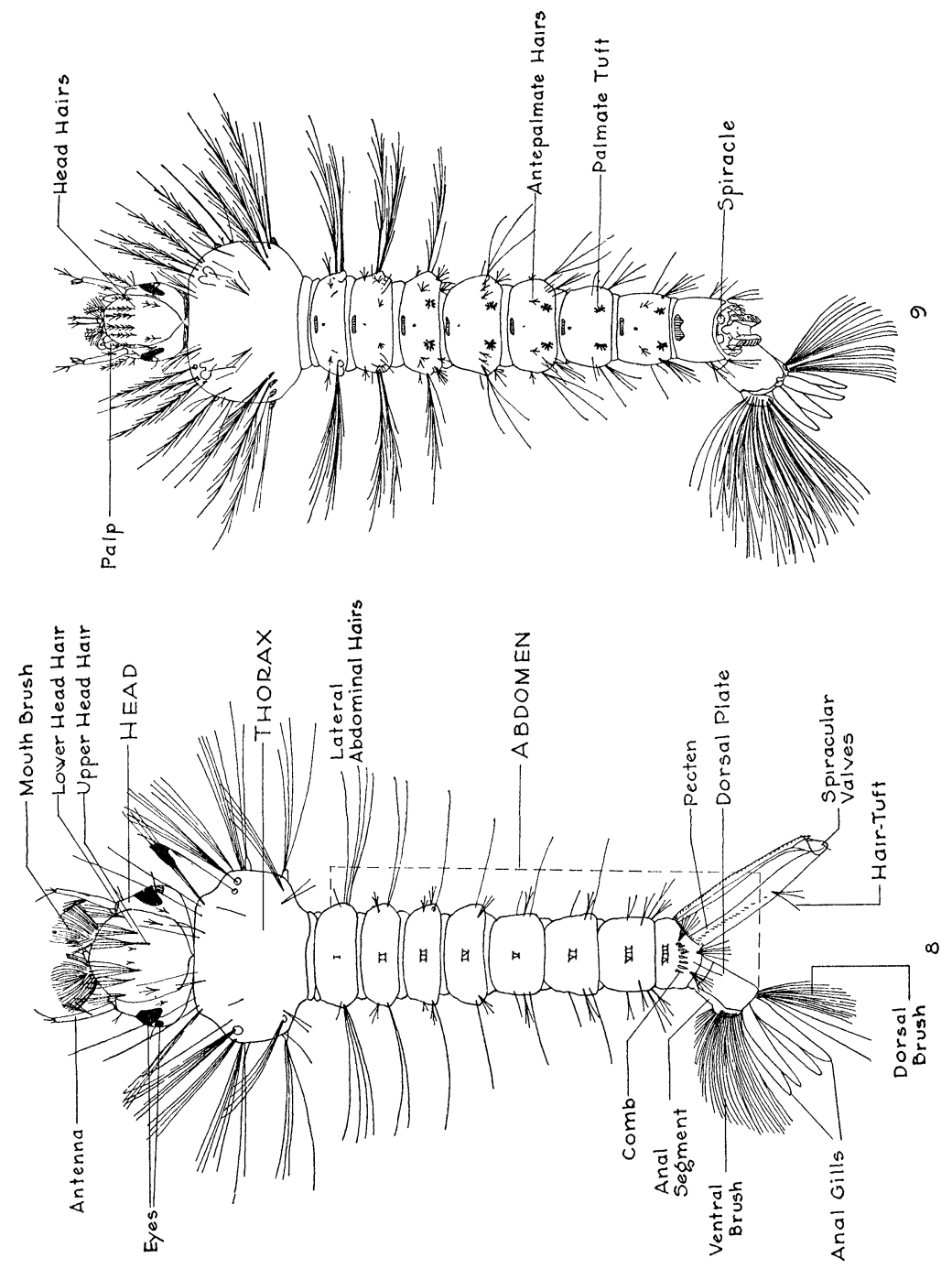

Tulloch-Mosquitoes of Massachusetts. 


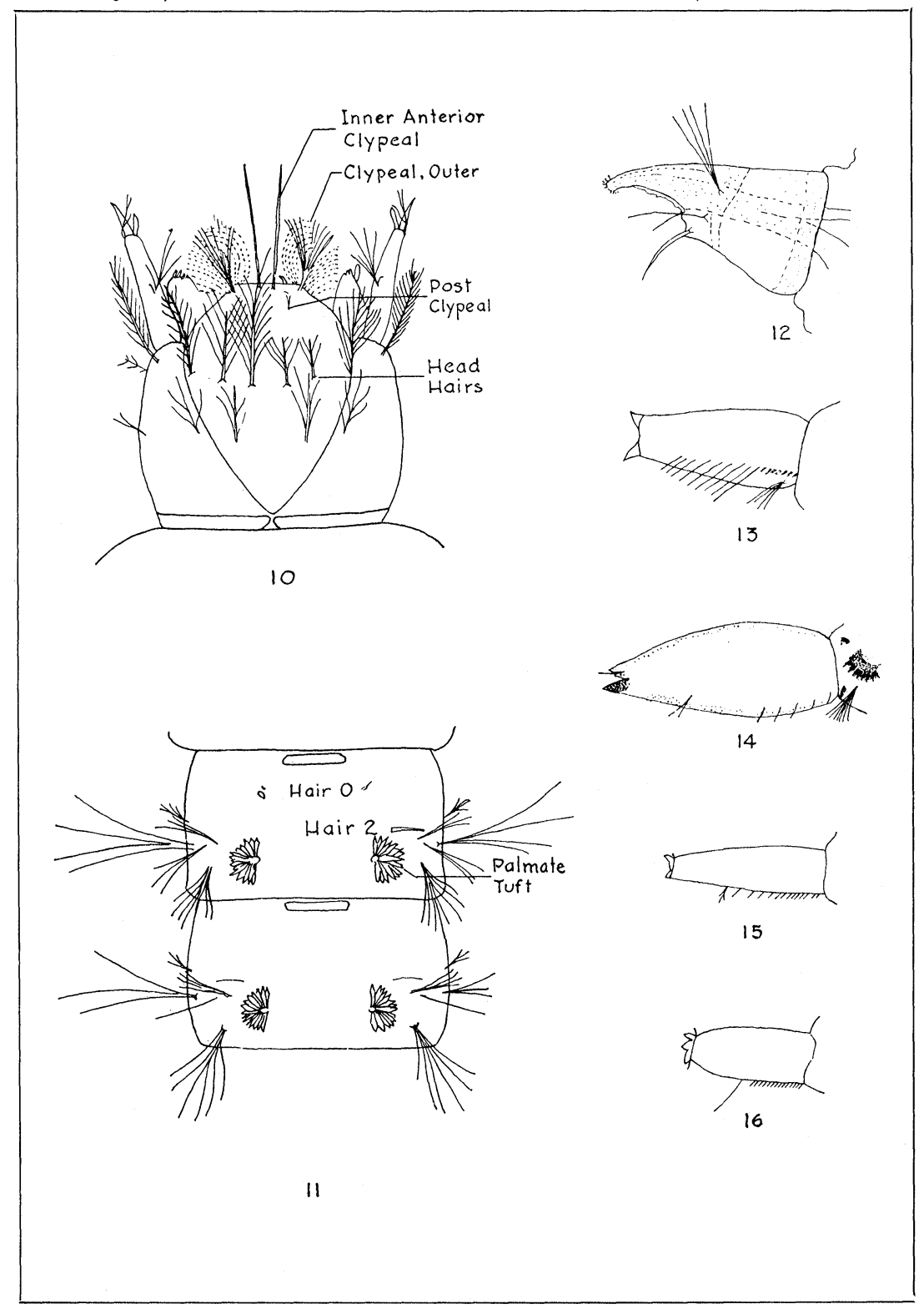

Tulloch - Mosquitoes of Massachusetts. 


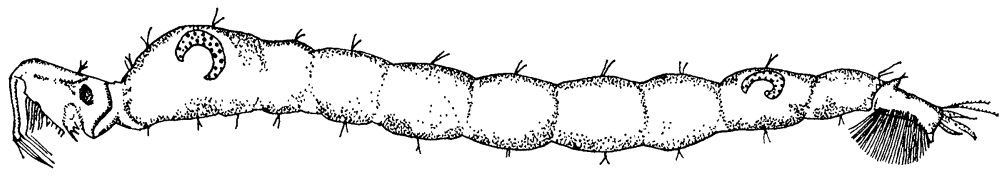

17

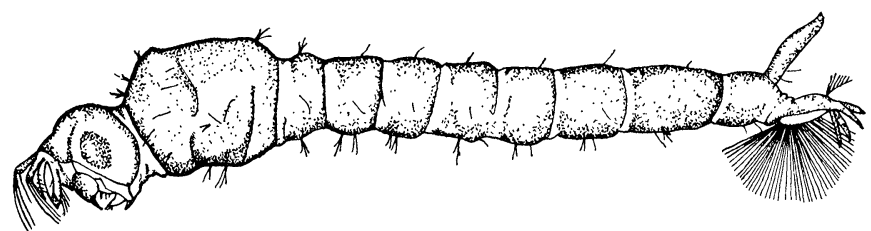

18

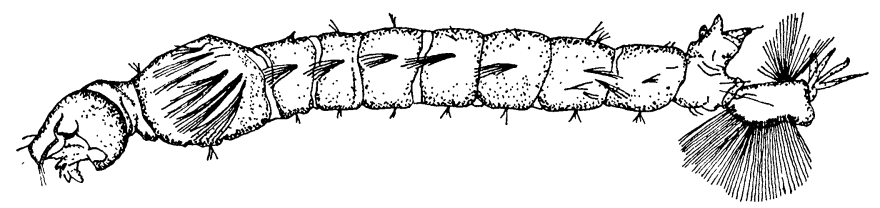

19
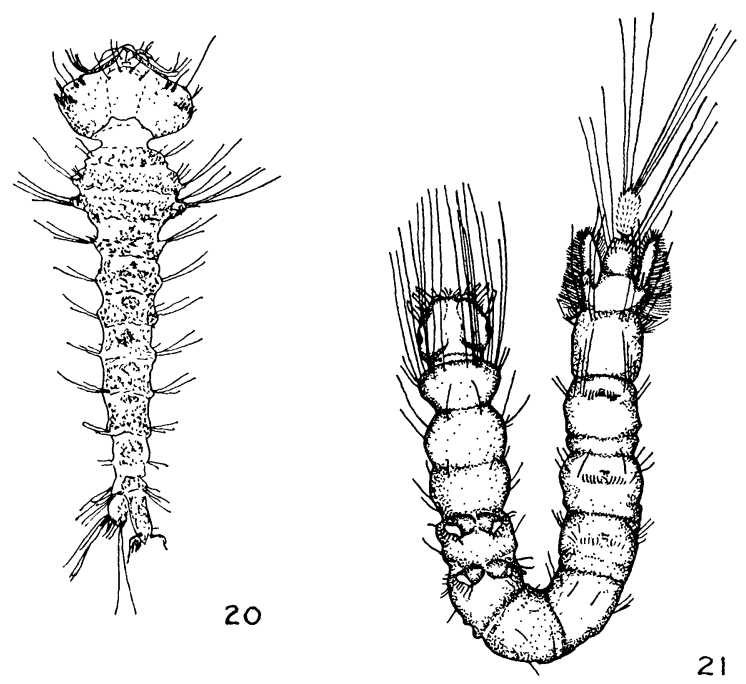

Tulloch - Mosquitoes of Massachusetts. 

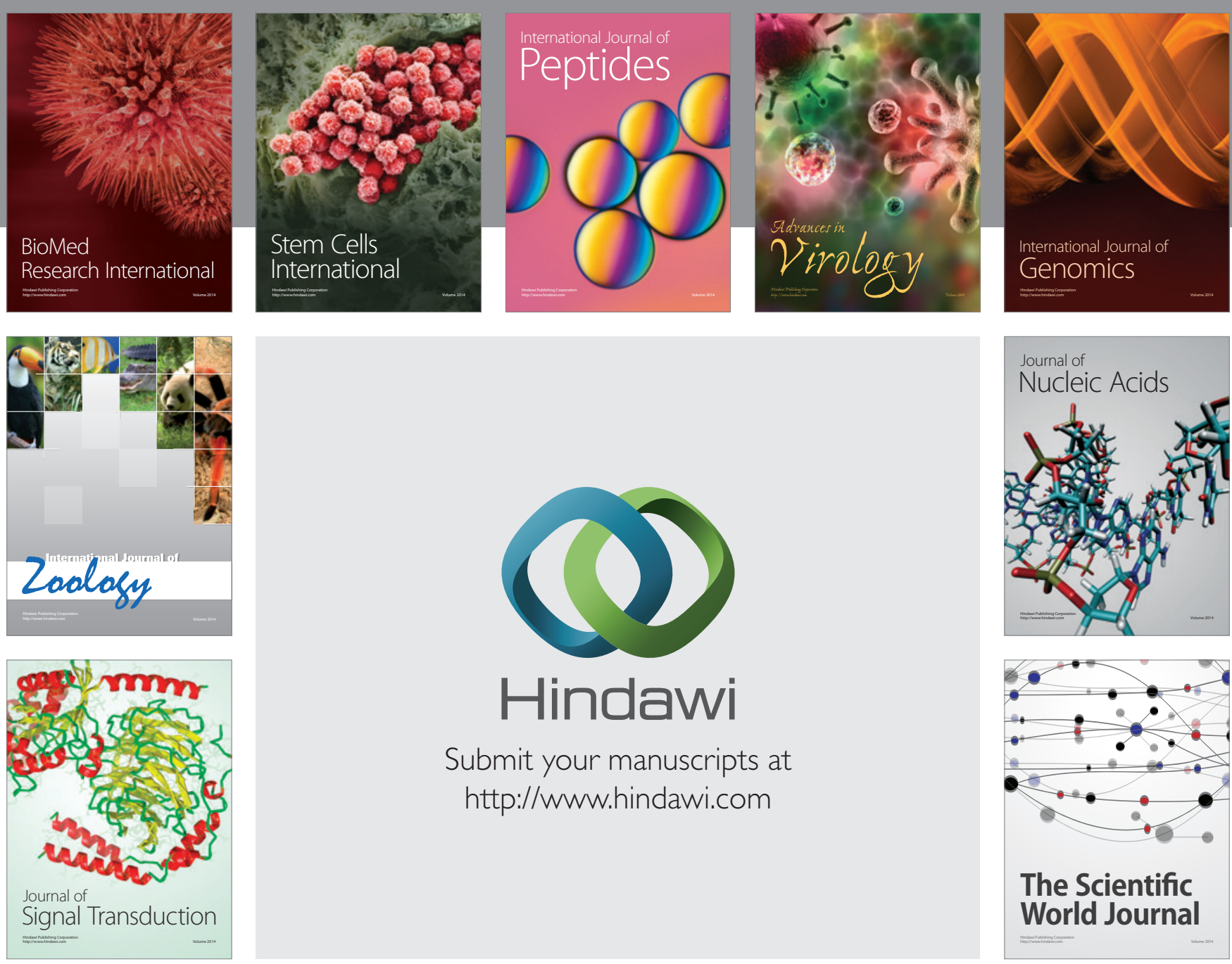

Submit your manuscripts at

http://www.hindawi.com
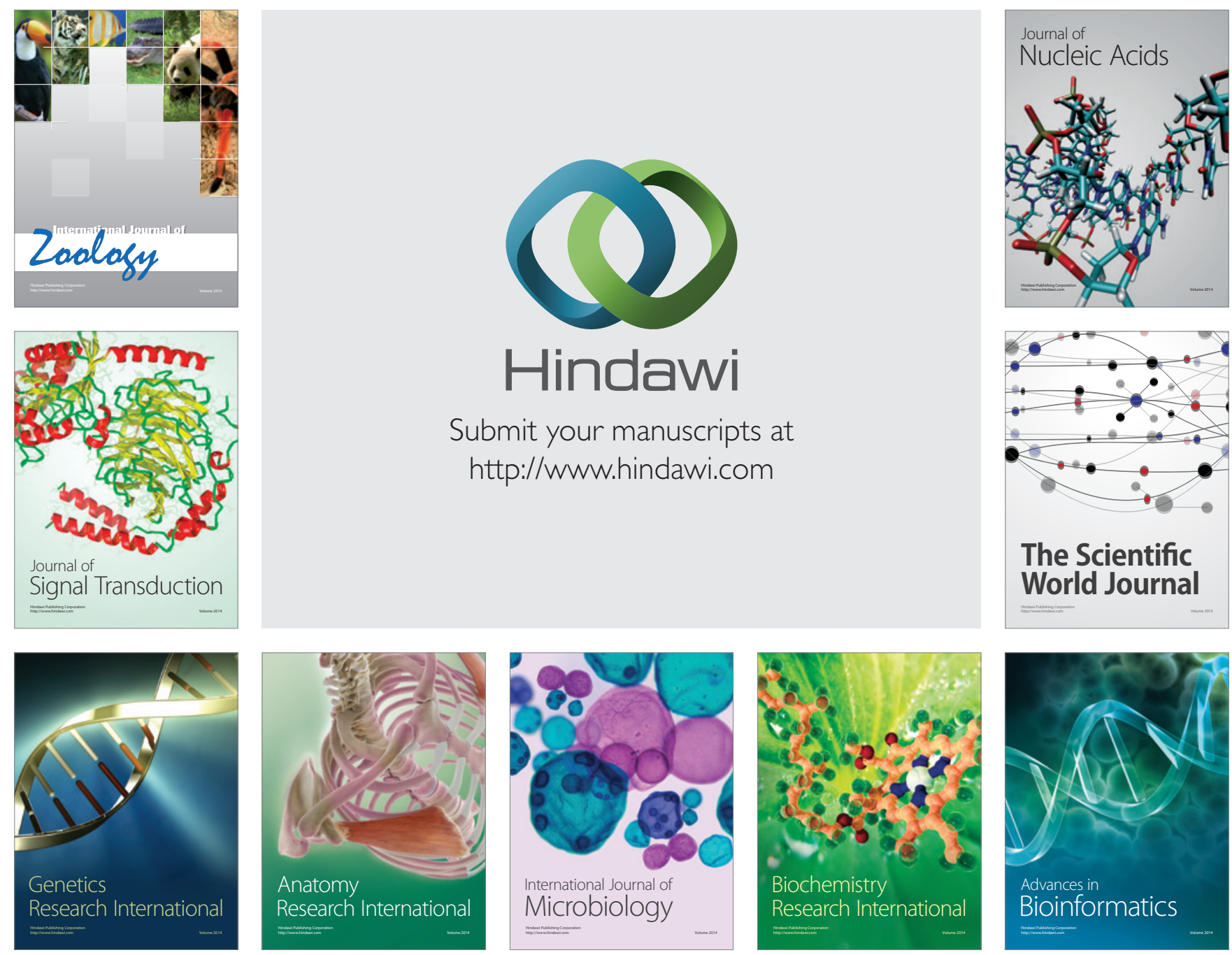

The Scientific World Journal
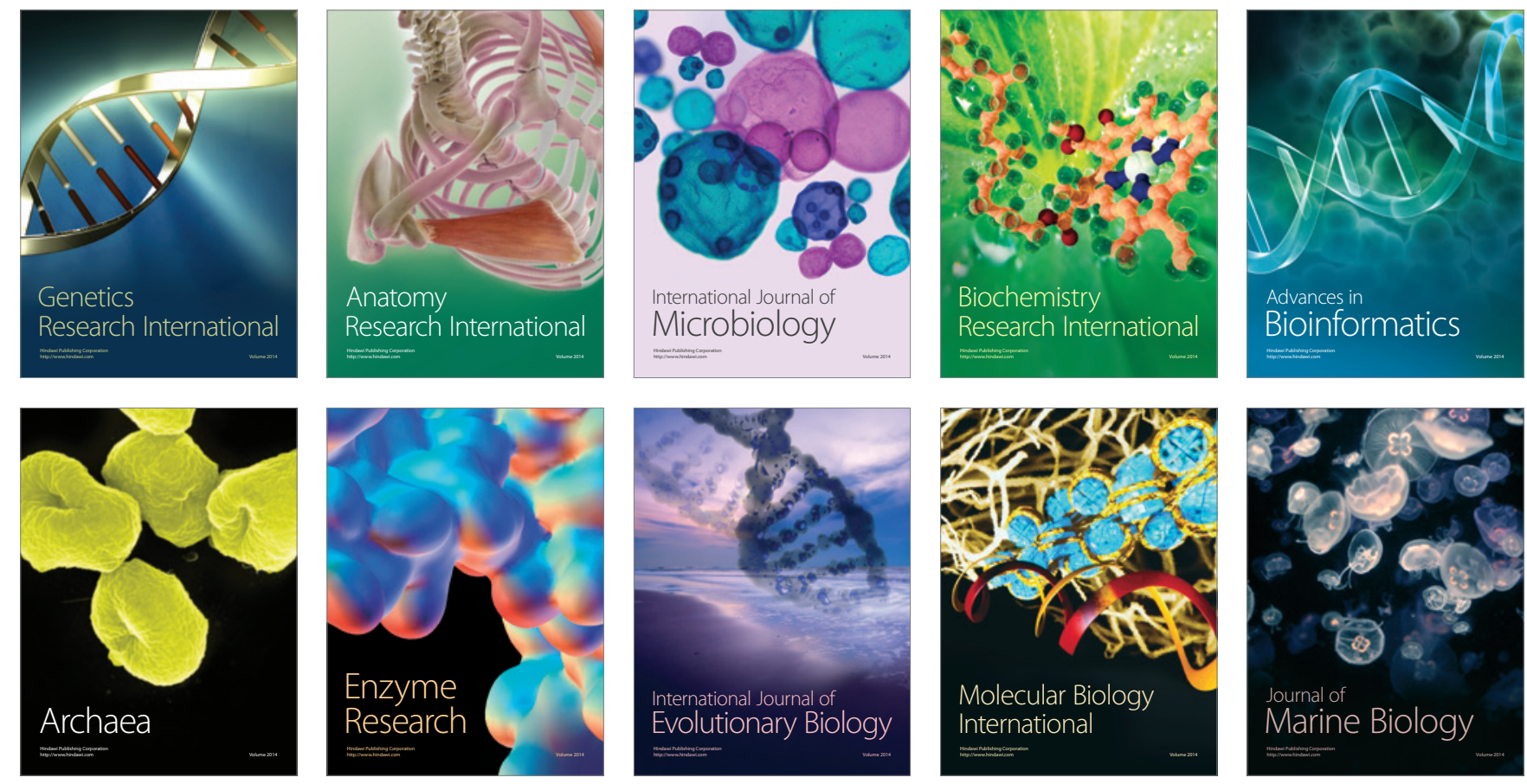